\title{
OSPREY RESCUES AT PREECEVILLE
}

LEONA POLLOCK, Box 255, Preeceville, SK S0A 3B0

In recent years, people who frequent the many lakes around Preeceville have become accustomed to seeing a large hawk fly over the lake and suddenly dive deeply into the water, only to emerge with a wriggling fish in its talons. A hawk that feeds almost exclusively on fish? Yes, the Osprey.

Osprey numbers plummeted throughout eastern North America in the 1950s and1960s, coincident with widespread use of DDT on forests and crops. Carried into the water by wind and surface run-off, DDT and its metabolite DDE accumulated in the fatty tissue of fish. Fish-eating ospreys accumulated the poison, resulting in thin eggshells, reproductive failure and a dramatic decline in numbers. ${ }^{2}$

Once DDT was banned for use in Canada, the U.S.A. and western Europe, in the early 1970s, Osprey populations began to recover. A survey in the 1980s showed that Canadian Ospreys accounted for slightly more than half of the estimated 17,500 to 20,000 pairs nesting north of Mexico. ${ }^{2}$

In Saskatchewan, Ospreys frequent lakes and rivers in mixed forest and boreal forest. In the 1950s, 1960s and 1970s no Ospreys were seen in the area surrounding Preeceville, although they were known to nest less than $50 \mathrm{~km}$ to the north of us, ${ }^{3}$ and although a river and seven lakes in close proximity would seem to offer prime habitat for them. In the last decade they have gradually increased until in 1998 there were three pairs nesting in the Nelson Lake - Lady Lake area, to the interest and delight of local residents.

So it was that after a violent summer storm on July 18, 1998, Sonya Kozmenuik, a teacher from Terrace B.C., vacationing at her parents' cabin at Nelson Lake, noticed that the Osprey nest on the top of a tall spruce beside the lake, had blown down. She phoned her dad, William Sawkiw, a member of our Kelsey Ecological Society, affiliated with Nature

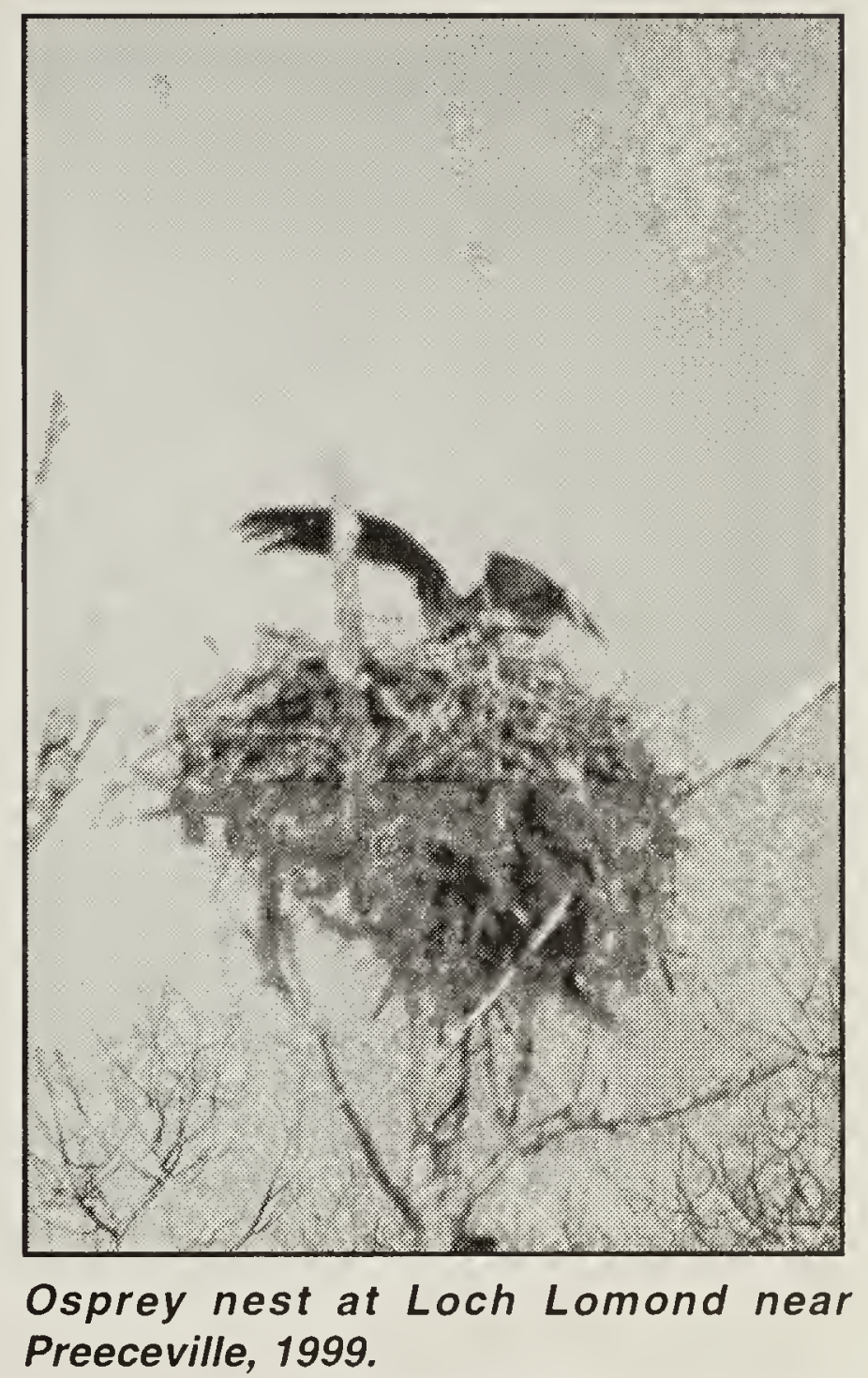

Photo by William Sawkiw

Saskatchewan. Unable to go due to bad health, Bill phoned another member, Norman Johnson from Ketchen. Norm went out to the site. After some searching, Norm found three young Ospreys, wet and chilled, on the ground, where their parents would not feed them. He put them in a towel-lined grocery box and brought them home. Several other Kelsey Ecological Society members went out to see the birds. They were of three distinct sizes. The largest had well-developed pinfeathers and wing feathers, and the smallest was almost bare, with just a bit of fuzz. It seemed there was about 10 days difference in age between each. Now the dilemma, what do you do with three young Ospreys, cold, hungry and obviously hurt? The smallest one was in much the worst condition. A quick call to Dr. Stuart Houston followed. He said it was important 
to get them back to the parents as soon as possible, by putting up a platform where the original nest had been; or if not possible, in a tree nearby.

We force-fed frozen smelts down the nestling's throats. Norman Johnson and Dallas Fairburn built a platform about $1.3 \mathrm{~m}$ square with an edging about $5 \mathrm{~cm}$ high around it. Next morning several Kelsey Ecological members, as well as Conservation Officer Ron Waugh, were at the site. The original nest site was inaccessible but another spruce, broken off in the storm, was chosen. The top was levelled, and the platform attached. Remnants of the original nest, along with small branches and twigs, were placed on the platform. Then the two largest Osprey were carefully taken up and placed on the platform. Ron Waugh thought that the youngest, unlikely to survive, was best put down, and we agreed.

It was about noon on July 19 when we finished. Then we backed off to wait. Would the parents find them? Would the "new" nest be accepted, in a location at least $10 \mathrm{~m}$ lower than the original? In almost no time we saw an adult Osprey calling and flying. About 6 p.m. it circled the new nest. The young were chattering. The adult made many loops around, then flew off to the northwest end of the lake. It returned with nesting material which it placed in the original nest tree. It stayed there for awhile chattering. It appeared that the adult was responding to calls from the young.

At 7:30 p.m. the adult perched in a tree, then came with food, landed in the nest platform, and appeared to be ripping apart the food. It then hopped up and sat on the butt end of the tree. There was movement; presumably the young were eating.

The following notes were kept by Cynthia Romiuk, a Kelsey Ecological Society member.

July 29: We observed the young feeding and flapping wings. When passing faeces, the nestlings put their hind ends out over the edge of the nest, thrust their tail feathers forward, and shot out a white stream. A cottage owner noticed the adult carrying nest material to the old nest tree again.

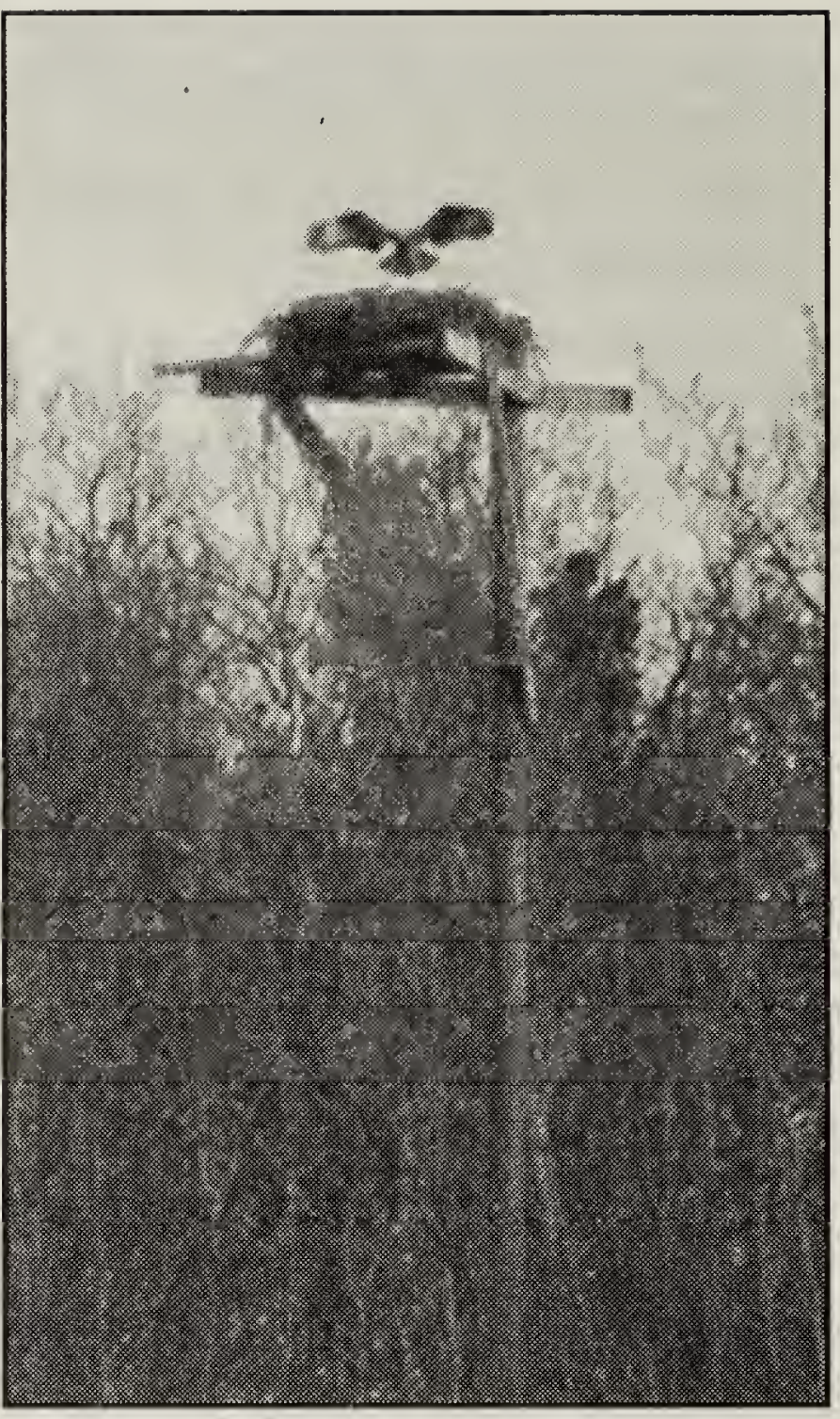

New Osprey platform near site of former Hinchcliffe grain elevator

Photo by Russ Peet

Aug. 5: An adult placed food on the nest platform, flew a short distance away and perched. It appeared that the young were tearing and feeding on their own. About this time, the smaller of the two Osprey was found dead on the ground below the box platform.

Aug. 7: Sonya Kozmenuik heard a new sound, and saw three Ospreys flying in circles. She thought it was the surviving nestling's first flight as it wobbled to and fro when perching on spruce tops.

Aug. 17: The remaining young Osprey was found flapping around on the beach, with an obviously damaged wing. The next morning, Muriel Mitchell, with the blessing of the Kelsey Ecological Society members, drove the young Osprey to the Small Animal Hospital in Saskatoon. It weighed $1.14 \mathrm{~kg}$, below the norm for its age. Dr. Colette Wheler determined that the left wing had had a break in the mid shaft radius and ulna, which had healed solidly but badly at $90^{\circ}$, and also had 
a dislocation of the carpus. Solid healing indicated the main fracture must have occurred weeks earlier. The right wing had a well-healed old break in the distal radius and ulna. It is thought that the bird tumbled in an early flight attempt and later re-injured the left wing. The doctors felt that three injuries were too many and an operation had no hope of success. Furthermore, Ospreys do not take well to being force fed. Reluctantly, the Osprey was euthanized. Kelsey Ecological Society members felt badly that their efforts came to naught after all, but they learned a lot in the process.

Another, more successful, Osprey project made 1998 truly "The Year of the Osprey" for the Kelsey Ecological Society members. For the last nine years the Saskatchewan Wheat Pool elevator at Hinchcliffe has had an Osprey nest on the very top. It was a huge nest, nearly $2 \mathrm{~m}$ deep, and because it was so visible, became a point of interest for naturalists for miles around, who watched the comings and goings of the Osprey with food for their young.

The Pool decided to tear down the elevator in the fall of 1998. Kelsey Ecological Society contemplated purchase of the elevator, as an historic site in its own right and to save the Osprey nest. All spring and summer dialogue continued between Kelsey Ecological Society, the Pool, and the Canadian National Railway (CNR), who owned the land. After many phone calls and letters, we reluctantly decided that it was not possible to save the elevator. We asked the
Pool to try to save the nest intact, which they did, by carefully removing the cupola on which it was situated. Within sight of the previous elevator site, on private land, three telephone poles were placed in deep holes by a work crew - who also lowered each pole in place. With financial assistance from the Pool elevator and CNR, Kelsey Ecological members then built a platform on top of each pole, adding one-third of the previous Osprey nest on each. The platforms are on private land.

In late April 1999, an Osprey pair returned to the platform closest to the railway track, and took up residence. This was expected, since experience at Loon Lake, Saskatchewan, and in Ontario, shows that platforms placed near former nests, have up to a $95 \%$ chance of occupancy in the first year. 1,2 However, the pair at Nelson Lake built a new nest in the original tree, forsaking the lower platform built for them. Other nests, one near the Assiniboine River, and another at the edge of Loch Lomond, were also active.

1. HOUSTON, C.S., and F. SCOTT. 1992. The effect of man-made platforms on Osprey reproduction at Loon Lake, Saskatchewan. J. Raptor Res. 26:152-154.

2. SCHNEIDER, D. 1994. Return of the Ospreys. Can. Geographic 114 (4):21-26.

3. SMITH, A. R. 1996. Atlas of Saskatchewan Birds. Special Publication \#22. Saskatchewan Natural History Society, Regina. 1996

You may have heard of the young robin who ate 14 feet of earthworm the first day after leaving the nest, or the house wren who was recorded feeding its young 1217 times between dawn and dusk. 